\title{
LINGUISTIC ASPECTS OF EVALUATING THE QUALITY OF EDUCATION ORIENTED TOWARDS MULTIPLYING HUMAN CAPITAL
}

\section{Grzesiak Jan}

\section{INTRODUCTION}

The issue of evaluating the quality of education in the context of human capital, as a kind of investment in the development of every person in a given education system, constitutes the subject of studies and academic research. Pedagogical and social literature includes more and more recent studies marked by the concern for improving the quality of education and upbringing in the contemporary education system in Poland and internationally. In this article, our attention will be focused on the issues of conducting evaluation research and implementing pedagogical progress in educational processes while investing in human capital, in particular the education of competent and responsible teachers. It should be emphasized that the classic concept of control and quality assessment is insufficient and requires intensification of actions for diagnosing and then constructing and implementing more effective solutions allowing for the execution of assumed educational goals while limiting capital-absorbency.

Practical procedures for developing so-called reports are assumed to be intended to reflect the quality of work carried out by teachers at every stage of education - in kindergartens, schools, and universities. Studies show that, in fact, they quite often do not present the actual results as measurable effects of the entire educational processes. The essence of a quality analysis, in the sense of analyzing the value of selected structural elements concerning these processes, consists in the search for the most effective and, at the same time, the cheapest methods in the context of their specific functions. Functions and functionality constitute the norms or categories of evaluating the activities of every human being (teacher), as well as human groups (teaching collectives) in the chosen field or a section of the evaluated reality.

In the production sphere, the dissemination of methods concerning value analysis leads to the dynamic development of new construction 
and technological solutions, the production of modified products, or completely new ones (clearly improved - fulfilling new functions). This is a characteristic phenomenon in the conditions of competition and free market economy. By analogy, there should be a need to create conditions for achieving significant added value as a measurable indicator of the quality of didactic and educational interactions at all levels of school and out-of-school education.

\section{Language education requires measuring and evaluating its quality}

The development of science requires searching for and creating more perfect, possibly the most optimal solutions based on the current state of scientific knowledge in a given field, supported by comprehensive practice. In order to meet the requirements posed by pedagogy as a social science, and thus, in order to guarantee dynamic progress and effective activation of mechanisms concerning this progress in education - an increasingly higher priority should be given to procedures for the analysis of pedagogical value in the enrichment of theory within the field of practice. And vice versa - in perfecting practical solutions it is necessary to fully respect the theoretical premises on the two-as-one principle ${ }^{1}$.

The fact that many pedagogical concepts have been rightly confirmed in educational practice without the use of value analysis, should be respected. That is because in the traditional education system randomness was sometimes decisive in terms of new and better solutions. There were also such circumstances in which the new, proposed and adopted, didactic solutions were better than the previous ones, although they were not necessarily the best among the constructed concepts concerning possible practical solutions. Such an approach usually becomes the direct cause for making changes by trial and error, and sometimes even rejecting a solution - which after a short-term use in practice turned out to be no better than the previous one. This leads to a conscious, or even worse, unconscious anomie as pathology. Just to mention, for example, the attempts of implementing in Poland the concept of such education which does not include the so-called

${ }^{1}$ Grzesiak J. Kapitał ludzki a jakościowo-aksjologiczne uwarunkowania studiów pedagogicznych nauczycieli. In: K. Denek, A. Kamińska, W. Kojs, P. Oleśniewicz (eds.), Aksjologia, innowacje i stratega rozwoju. Sosnowiec, 2011, s. 219-235. 
homework under the guise of not assigning the students with excessive duties - otherwise understood as education without stress. Currently there is a disturbing phenomenon of undermining or even a harmful loss of a teacher's rank of authority. This is manifested, for example, by carrying out social (media) discussions concerning education and the quality of teachers' work, in which, surprisingly, teachers themselves do not take part. The actual results of such (pseudo) reforms disadvantageously significantly diverge from the assumed goals. Scientific research carried out at various centers confirms a reduction in the effectiveness of education and upbringing at various stages of education, not excluding teacher education. There is no doubt that only in the course of dialogue it is possible to create conditions for a successful development of education for today and tomorrow - the day after tomorrow ${ }^{2}$.

The shortcomings in searching for better solutions in education through alleged research are described by H. Muszyński in the following words: "...pedagogical research is subject to disturbing phenomena, when without any verification, even on a tiny material, various ideas are directed towards the path of mass implementation.... The mechanism of creating an experiment is usually based on the fact that researchers are looking for good and sometimes very good schools, and carry out studies in them. Then they state what has already been... it is a mechanism that does not require to be launched, because everything was known in advance. The task of the experimenter is to convince that in typical conditions results are achieved proving that what has been done, gives real effects, and is profitable" ${ }^{3}$.

Quality analysis in pedagogy should become a method of organized search and implementation of new solutions and innovations, and thus becoming a valuable method in creating pedagogical progress. W. Okoń in the "O postępie pedagogicznym" thesis reports that "... pedagogical progress consists in the transition from a lower to a higher level of development of individual people, as well as educational and upbringing institutions, also the general conditions of educational-upbringing influence. At the same time, the measure of progress consists in

${ }^{2}$ Grzesiak J. Ewaluacja w dialogu-dialog w ewaluacji. In: Grzesiak J. (eds.), Ewaluacja $i$ innowacje w edukacji. Kalisz-Konin, 2008.

${ }^{3}$ H. Muszyński, Pojęcie systemu i jego konsekwencje. In: W. Okoń (eds.), System dydaktyczny, Warszawa, 1972, s. 211. 
achieving better and better results in the same or shorter time, using more and more rational methods and means, as well as a reasonable increase in expenditures" 4.

The term provided by $\mathrm{W}$. Okon grasps pedagogical progress in the aspect of taxonomic comparison of measurable effects of work while taking into account better methods and means of implementation, as well as the appropriate financial expenditures. Etymologically, the word "progress" (Latin progressus) means moving forward, striving for something better, improvement - and so it expresses one of the basic attributes of the world's existence. Thus, "pedagogical progress" is understood broadly. Speaking of pedagogical progress, it is difficult to underestimate the methods of a qualitative analysis in its creation. Properly conducted quality analysis should completely eliminate randomness, at the same time guaranteeing access to the most optimal solution in the existing conditions, taking into account the current state of knowledge in a given field of science. One of the elements of pedagogical progress is the improvement of the didactic-educational system as a complex and comprehensive whole. All individual elements of the didactic-educational system serve the purpose of achieving a proper goal - a task, meaning fulfilling certain specific or unspecified functions. In contrast to traditional methods of improving and rationalizing activity, focusing on a given item and its individual functions - the value analysis is characterized by a comprehensive assessment of all factors affecting the functionality and effectiveness of school practice. In educational processes as well as the processes of measuring and evaluating the quality of this work's value analysis, complex team work closely related to the individual effort of absolutely all team members, constitutes an essential element, fundamentally different from traditional methods of pedagogical progress 5 .

The result of the work carried out by a team that performs quality analysis should consist in a solution such as a handbook, which would reflect the latest scientific achievements in the field of psychology and theory of education, but also fulfill all the functions determined by the

${ }^{4}$ W. Okoń, O postępie pedagogicznym, Warszawa, 1970, s. 17.

${ }^{5}$ See. eg. J. Grzesiak, Przez analizę wartości do postępu pedagogicznego. In: T. Zacharuk (eds.), Ciagłość $i$ zmiana $w$ pedagogice XXI wieku, pt.1. Siedlce, 2007, s. 279-287. 
theory of a school handbook, possibly supplemented by the value analysis team ${ }^{6}$.

\section{The procedure of value analysis versus linguistics}

Above all, we cannot forget that the necessary condition for the effective work of the team performing value analysis is above all thecomprehensive and precise knowledge of the structure of the considered component of educational processes subjected to valuation. Connections and interrelations between the quality and the analysis of the value (evaluation) of education indicate the specific relation between the research issues, and even the importance of scientific cooperation between universities conducting such research, be it in evaluation or in the field of measuring and evaluating quality in education ${ }^{7}$.

The orientation of modeling and didactic designing procedures to obtain the highest degree of compatibility between the assumed and achieved effects of the education process on the part of each pupil (student) requires consistent respecting psychopedagogical principles of educational diagnosis. The full cycle of psychopedagogical diagnostics consist of the following stages:

1) diagnosing the object (unit, group),

2) interpreting the data obtained within the diagnosis,

3) drawing conclusions referring to further educational proceedings in the diagnosed case,

4) designing programs (new solutions) for the diagnosed object,

5) evaluating the proposed proposals and selecting the most optimal program (project),

6) implementing the selected (relatively optimal) program $^{8}$.

${ }^{6}$ See. eg. W. Okoń, Podstawy wykształcenia ogólnego, PWN, Warszawa 1968, pp. 235-257; J. Grzesiak, Metodologiczne uwarunkowania modelowania podręcznika dla klas początkowych. In: A. Mościcki (eds.), Teoretyczne i praktyczne aspekty metodologii badań podręczników szkolnych. Koszalin, 1986, s. 156-171.

J.Grzesiak, Założone a rzeczywiste kompetencje nauczycieli wobec poprawy jakości kształcenia. In: A. Klim-Klimaszewska (eds.), Kompetencje wspótczesnego nauczyciela, tom 1, UPH, Siedlce, 2012, s. 35-46.

8 J. Grzesiak, Modelowanie projektowania poprawy jakości kształcenia wyzwaniem dzisiaj -wczoraj i jutro. In: J. Grzesiak (eds.) , Ewaluacja i innowacje w edukacji, Kalisz Konin, 2013, s. 11-18;

S. Palka, Wiązanie operacji poznawczych i metodologicznych w pedagogicznych badaniach edukacyjnych. In: K. Denek, A. Kamińska, P. Oleśniewicz (eds.), Edukacja jutra, Tradycja $i$ nowoczesność we współczesnej organizacji systemu kształcenia, Sosnowiec 2013; B. Niemierko, Diagnostyka edukacyjna, Warszawa, 2012. 
The general analysis of the semantic side and substantive content of successively highlighted stages allows to notice that the keywords used in the formulations of each of points 1) to 6) are inextricably linked to the methodology of social research, and in particular the methodology of pedagogical research. This means that entities undertaking tasks requiring a thorough diagnosis and evaluation of a given facility or educational phenomenon should have comprehensive preparation in the field of educational research methodology.

The success of a value analysis depends to a large extent on the precise determination of the purpose for which the subject of the research is to serve, i.e. to determine its function. The definition of a function cannot be included in a narrower or broader sense. In the first case, the possibilities of finding a better solution are limited, while in the second case, the search for new solutions causes dispersion and ambiguity. After determining the list of functions and necessary, which should be fulfilled in the practical application of a specific solution to the problem, it is possible to assess what functions have not been met in the current solution in practice. Such assessment should be based on comprehensive and exhaustive research on the effectiveness of the current solution. The methodological foundations of such research should take into account the latest achievements in the theory of measurement in pedagogy.

Diagnosing and putting forward proposals regarding the functioning of the current solution to the problem requires the provision of comprehensive and reasonable answers to three basic questions:

1. Does the studied solution to the problem meet all the assumed necessary functions?

2. Is the issue currently being considered unnecessary?

3 . Is the currently used solution optimal?

Based on the results of empirical research and the results of the analysis relating to specific functions and requirements, it is necessary to determine what unnecessary functions are currently met by the solution to the problem. The removal of unnecessary functions is an indispensable condition for improving efficiency and functionality. The analysis of the value of a certain solution may sometimes be executed already by the elimination of unnecessary functions fulfilled by the currently functioning solution to the problem. 
Knowing what essential functions does the solution in the present functioning meet and what functions it does not meet, provides the basis on which the solution can be assessed. Recognizing the current solution as not the best one, not the most advantageous one in the current state of science and technology suggests reflection and forces us to look for new, better solutions to the examined issue.

The search for new solutions to the problem is a very important link in the value analysis. It leads to the formulation of various concepts of new solutions that would meet the assumed necessary functions. The methodological basis of the search for these solutions is captured in the two following phases:

1. Challenging everything that is currently functionning in the field being studied (negation - criticism),

2. Developing the concept of new solutions that meet certain necessary functions.

The creative attitude of the value analysis team is conditioned by a negative and critical attitude to the examined section of reality. Neglecting or questioning the currently functioning solution puts the team members in a problematic situation, and thus is a motive for the team work ${ }^{9}$.

Producing ideas for solving the problem under investigation by each member of the value analysis team enriches the current state of knowledge in a given field and reduces the problem situation to a nonproblem one. At this stage of the team activity, any idea, even raised by a non-member of the team, is very valuable. Pedagogical progress can be made with the active participation of eminent practitioners who, based on the experience gained and the conclusions drawn from their practice, can significantly contribute to filling the gaps inherent in the pedagogical theory itself. A general and wide-ranging discussion on a given topic can often provide many very valuable ideas, and can even indicate the most optimal solution to the problem.

The next, third stage consists of the analysis of the value of newly designed solutions. The value analysis team first establishes a list of new functions and unnecessary functions contained by each of the new solutions. On this basis, the team analyzes, verifies and corrects new proposals in order to create the most perfect concept of a new, final

\footnotetext{
${ }^{9}$ J. Kozielecki, Rozwiązywanie problemów.Warszawa, 1969, s. 31-35.
} 
solution to the analyzed problem. This requires answering the following questions:

1. What new features are introduced by the new solutions to the problem?

2. Do the new solutions introduce unnecessary functions?

3. What new solution is the most optimal?

As new functions, introduced by a solution to some problem, should be treated only those functions that were not present in the existing solutions, but are not unnecessary functions and have a positive impact on increasing efficiency when the adopted solution is applied in practice. Similarly to the previous solutions to the problem under consideration, also the new ones should be analyzed in terms of fulfilling redundant functions. Freeing the new solution from any unnecessary functions may make it relatively optimal in a given field.

The solution that introduces the largest number of new functions and at the same time does not contain unnecessary functions, or contains the least of unnecessary functions amog all the suggested solutions (which for various reasons cannot be eliminated from the qualitative analysis procedures) is considered the most optimal. The solution considered to be the most optimal with the current state of knowledge, after a certain period of its application will require further modifications in practice.

The quality analysis in education must reflect the fundamental principles of operation in a social system. The following principles deserve emphasis: functionality, structurality, activation, design and the principle of flexibility. If we accept the organization of all activities as the incarnation of the goals function, then the analysis of values in pedagogy can be treated as an inspiring, regulating, checking and improving factor that realizes the function of goals in different scopes and multiple perspectives. In the field of education and upbringing, due to the basic conditions and goals and the corresponding tasks, taking into account the distinguished principles is imperative for "contributing to the success of the whole" and for comprehensive pedagogical research.

Rational triggering of conscious activity, supported by knowledge and social experience of every human being, is one of the basic conditions for avoiding mistakes in further actions. Extending the circles of people and organizations can contribute to the realization of socially important pedagogical goals as well as intensifying activities that 
promise the achievement of these goals. Cooperation, understood as programming of the activities of the value analysis team, is one of the basic conditions, the observance of which enables efficient and effective execution of the tasks undertaken.

The broadly treated method of value analysis in making pedagogical progress cannot, however, be overly bureaucratic. That is why the principle of flexibility is particularly important in creating pedagogical progress through value analysis.

In striving to improve the quality of functioning of a modern school, the method of value analysis sets the directions for action of many entities, including evaluation and self-evaluation procedures referring to all teachers without exception and to all teaching teams. Only with collective action, commitment and responsibility can the practice in Polish education be improved today and tomorrow ${ }^{10}$.

\section{Methodological aspects of qualitative research in language education}

This part of the article will present a proprietary approach, which was constructed with a focus on the basis of separate subjects of teaching education including, among others: research methodology, psychopedagogical diagnostics (didactics (theory and methodology of education) and didactic design. The participants of the teacher education process have all to face the follwoing task: make a comparative analysis of selected practical or theoretical solutions concerning the same subject in the substantive and methodological aspect.

Due to the limited framework, we will quote here fragments of the content of the instruction addressed to the student of pedagogy:

The comparative analysis should take into account the whole view of the problem by selected (2-3) authors and should not be limited to considering publications separately from a given point of view. The two levels of the content of the publication, which are particularily important to us - the substantive and methodological one - are related to each other. However, they should be distinguished in order to thoroughly analyze the literature and to express our own judgment.

${ }^{10}$ W. Kojs, Funkcje teorii w działaniach edukacyjnych nauczyciela i ucznia - szkic analizy zagadnienia. In: J. Grzesiak (red.), Ewaluacja i innowacje w edukacji nauczycieli, tom 1, Kalisz, 2007, s. 59-68. 
Analyzing the literature from the substantive side, we should first of all:

a) pay attention to the terminology used by the authors (including the content and scope of each of the basic terms (or a group of concepts) related to the topic of the work, to emphasize the mutual relations between concepts (supremacy - subordination),

b) select contents that relate to the topic (goal) of the study,

c) determine what issues are covered by each of the authors,

d) extract the judgments and theorems of the authors regarding the analyzed issues.

When analyzing publications in terms of methodology, it is important to pay attention to the way in which a given author has come to his/ger own conclusions, and whether and how he / she justifies them. Due to the specificity and complexity of the methodological approach to the chosen topic, one can limit ourselves to the methodological aspects of the compared publications. There may be also publications in which the methodological aspect will not be discussed (in such a case it should be clearly emphasized during the analysis and this fact should be evaluated).

The nature of the literature being compared should be emphasized. Due to the starting point for the authors' reasoning and because of the generality of their statements, one could speak about theoretical publications, publications based on empirical research or about works based on insights and reflections from practice in a specific time or spatial range.

Theoretical considerations, generalizations referring to the surveyed collectivity and observations from the practice may occur to various degrees in individual studies, for example, in theoretical work data from empirical research can be cited as examples illustrating the issues discussed. It is possible to distinguish written works with different scientific values. Therefore, the analysis should distinguish, for example, statements of a general or intuitive nature from generalizations derived from empirical studies (generalizations of varying scope) or from conclusions formulated in the deduction procedure.

In the case of works based on empirical research, the following issues should be taken into account: a) research problems, b) hypotheses, c) variables, d) conditions in which research was carried out, e) research procedure (strategies, methods, techniques), 
f) characteristics of the surveyed individuals or collectivities, g) obtained results, h) conclusions derived from these results, i) interpretation of the results and discussion or unexplained issues, as well as j) conclusions, demands and desiderata focused on the real improvement in the examined piece of reality.

In general, attention should be paid to whether and to what extent the authors of the compared works undertake attempts to synthesise and structure knowledge in a given area of reality. The following criteria questions - can be used for this purpose:

a) on what theory (existing - more or less developed) do the authors base their arguments.

It should also be emphasized whether the authors refer to theorems and hypotheses of a given theory in order to explain the studied processes, whether they use terminology appropriate for a given theory, etc. As a result, orientations and trends in the development of a selected scientific-research area may be noticed and formulated,

b) what is the nature of the research problems deliberately posed by the authors (are they open - complementary - problems, or empirical - verification - problems, whether they concern innovative issues not yet explained or partially confirmed by science, practical problems, theoretical-practical or practical-theoretical problems etc.); The nature of the problem can be determined on the basis of knowledge of the scientific achievements in the field of the analyzed problem. When undertaking research and formulating research problems, the author should stay aware and not "balance the open door", but continue the work of his/her predecessors according to the principles of continuity and change in the development of education and the science related to it,

c) to what extent the results of one's research or analyzes are linked and confronted by the author with the current achievements of science in this area (This is a question related to the evaluation of publications due to the criterion of synthesis and generalization by the author of knowledge in a given subject of research);

After drawing up a sketch of the structure of one's own work and the analysis of each publication, comparisons are made. In situations where differences are found, one should consider their causes, significance and the discrepancies observed. The reasons for possible differences can be seen, among others at the methodological level of the 
analyzed studies. The differences in research results may be related to the fact that each of the authors studied the population in a different area, at different times or with other features (e.g. the diversity of students in the class).

It may be advisable to re-check and re-examine the claims formulated by the authors. Maybe they are formulated so precisely, that they should be reduced to certain specific cases - they concern, for example, students with special musical interests, which we could not notice in the current comparative analysis. When making comparisons, it should also be taken into consideration that the same terms in different authors may have a different meaning - and vice versa - the same content may be formulated with different notions. In addition, comparisons must be made for genuinely comparable elements, i.e. for judgments regarding one issue treated by author X and author $\mathrm{Y}$. It is not possible to compare the judgments regarding various issues.

On the basis of a thorough analysis of literature and own reflections, one should try to formulate one's own conclusions regarding the subject being developed. Particular attention should be paid to the construction of the work: the arrangement of individual parts, paragraphs and sentences. It should be a coherent text, without numerous quotes or summaries, and at the same time without any mental leaps, without unnecessary repetitions.

Particular parts of the work must be proportional - without excessively broadened sections or isssues treated very briefly in comparison with others. It is necessary to distinguish the subsequent content sequences and parts of the study - paying attention to the flexible transition from previous parts of the work to subsequent ones. Such a solution requires from the academic teachers a frontal approach to education in the aspect of the graduate profile of a particular specialty. Experience shows the need to help students learn in such a problem-based study. This issue requires the development of a specific methodology of studying in terms of vocational education for teachers today and for tomorrow.

The methodological approach presented can also be used in other subjects of education, the essence of which is shaping the key competences of students in the scope of making comparative analyzes of the bibliographic sources they study, including methodological ones. 


\section{Conceptualization - For a higher quality of qualitative research in language education in the era of the information society}

The measure of the social role of pedagogy as a science is always its ability to face the contemporary challenges, or to describe and explain the phenomena that constitute the surrounding reality and directly impact the currently functioning of educational practice. One of the ideas distinguished in pedagogy is to define the process of education as the contact of the human individual with objective values and cultural goods, their intercession, and thus enrichment of the spiritual strength of human being and creation of new values. As B. Suchodolski rightly notes, the vision of the future creates a picture of past times, just as the lasting trend of tradition determines the nature of intentions and the specific style of their implementation ${ }^{11}$.

In pedagogy there is an increasing dilemma between the relationship between pedagogical theory and educational practice. Many scientific centers and publishing houses clearly deviates from the paradigm of pedagogy, primarily due to the so-called postmodern breakthrough. S.Palka's research has shown that over $80 \%$ of teachers with professional pedagogical preparation understand pedagogy as an instrumental discipline with respect to the existing educational practice $^{12}$.

The changing conditions for attaining the goals of education and upbringing in the contemporary Polish school entail the necessity of a teacher's creative attitude towards social changes and emerging new educational situations - such statement is obvious and can be often found in pedagogical literature. The creative attitude of the teacher is conditioned by having knowledge and competence in the field of diagnosis, evaluation and didactic planning. Hence, in the process of teacher education, great importance is attributed to such subjects as the psychopedagogical diagnostics, the methodology of social research (especially pedagogical) and seminars related to the construction of an independent thesis (diploma), among others. In addition, student groups and research camps are also a valuable form of education in this field. The education of good teachers should enable the optional gaining in the

11 B Suchodolski, Dzieje kultury polskiej. Warszawa 1986, p. 6; see also: J. Grzesiak,Autoewaluacja i refleksyjność nauczyciela w pedeutologii, w: J. Grzesiak (eds.), Ewaluacja i innowacje w edukacji. Konin, 2007. 1989, s. 118.

${ }_{12}$ S. Palka, Teoria pedagogiczna a praktyczne doświadczenia nauczycieli. Warszawa, 
course of study additional skills, which are necessary in the school environment to conduct artistic teams, organise tourist or extra-curricular activities, etc. Many publications draw attention to the need to reform the teacher education system ${ }^{13}$.

School education and learning about it currently faces the need to help teachers, pupils and their parents learn, discover, feel, understand and prefer values as an ethical norm. this in turn drives the increase to a large size of the axiological foundation in the education of teachers and their professional activity, consisting of a triad: knowledge efficiency - value. As it is rightly pointed out by K. Denek, the category of values occupies the least space in education, and the reliable implementation of the first two (knowledge - efficiency) depends on the criterion of value ${ }^{14}$.

The teacher must be aware of the existence of the subject - the pupil, in order to be able to open himself / herself to the pupil's experience. The relations teacher-pupil (and subsequently teacherpupils) should be based on truth and mutual responsibility for the world of values that constitutes all human activities. This also involves being open to perspectives that exceed stereotypical thinking about difficult current times ${ }^{15}$.

The greater appreciation should be given to those teachers who are able to meet the difficult art of valuing in such a way so that the pupils could find sens in the world of different axiological orientations. Therefore, in education, including teacher education, it is impossible to underestimate the importance of value as a categorical norm in school education - their category, classification and interpretation ${ }^{16}$.

The analysis of the standards set for teaching studies and for the pedagogy, despite its generality, allows to notice imperfections and threats inherent in the concept of teacher education ${ }^{17}$.

${ }^{13}$ See for ex. K. Denek, O nowy kształt edukacji. Toruń, 1998;

K. Denek, Aksjologiczne aspekty edukacji szkolnej, Toruń, 1999;

H. Kwiatkowska, Edukacja nauczycieli. Warszawa, 1997;

D. Jankowski, Autoedukacja wyzwaniem współczesności, Toruń, 1999.

${ }^{14}$ K. Denek, Wartości i cele edukacji szkolnej, Poznań-Toruń, 1994.

${ }^{15}$ J. Mastalski, Etos nauczyciela XXI wieka a stereotypy edukacyjne. In: J. Grzesiak (eds.), Ewaluacja i innowacje w edukacji nauczycieli, vol. 1, Kalisz, 2007, s. 136.

${ }_{17}^{16}$ K. Denek, Wartości ..., op. cit., s. 36-39.

17 Rozporządzenie Ministra Edukacji Narodowej z dnia 17 stycznia 2012 r. $w$ sprawie standardów kształcenia nauczycieli. 
Teacher's specialization in the course of higher education includes directional education - substantive training in the field of subject matter (classes), conducted within the field of study in such a way that the graduate acquires knowledge and skills appropriate for teaching the subject (classes); teacher education - preparing for the implementation of didactic, educational and caring tasks, conducted in conjunction with directional education and pedagogical practices; education in the field of information technology - preparing for the use of information technology, including its use in teaching a subject (conducting classes); education in the field of foreign language - enabling the acquisition of advanced language skills at least at B2 level and pedagogical practices - serving the acquisition and development of professional skills through practical classes with students, as well as enabling the cognition of the organization and functioning of schools and institutions, implemented in conjunction with teacher education $^{18}$.

The introduction of core curricula at the level of school education, as well as education standards and recently the national qualifications framework at the university level is, by definition, an important basis for improving the quality of education. In fact, respecting certain standards in curricula, and even more in school textbooks, raises many doubts and controversies. This is due to the fact that the construction of textbooks and other didactic materials, despite the progress of information technologies, do not reflect the premises of psychological and pedagogical theories ${ }^{19}$.

It turns out that in reforming Polish education and in the procedure of creating conditions for the implementation of reforms, there is, in educational practice, a clear gap between the theory and its implementation. This is why it is necessary to conduct wider diagnostic and evaluation tests that require evaluation of didactic and educational effects. For it is only on this basis that it will be possible to construct new rational solutions aimed at improving the state diagnosed in the educational reality.

18 J. Grzesiak, Podstawy teorii i metodyki kształcenia praktycznego nauczycieli. Konin, 2010.

19 See for ex. K. Denek, O nowy ksztalt ... op. cit.; K. Denek, I. Kuźniak, Projektowanie celów kształcenia w reformowanej szkole, Poznań, 2001;

J. Grzesiak, Rzut oka wstecz wobec edukacji jutra. In: K. Denek, T. Koszczyc, W. Starościak (eds.), Edukacja Jutra, vol. 2, Wrocław, 2009 . 
My research among students of teaching faculties has shown that too much educational content requires them to laboriously learn by heart, while the expectation of future teachers is eloquently large regarding the content particularly useful for the performance of pedagogical work at school. The respondents did not hide the selfcritical attitude towards their own competences shaped allegedly during the studies to prepare oneself to work as a teacher. Almost $40 \%$ of respondents did not hide their fears as to whether they are prepared for the direct interaction with pupils in the classroom after graduation.

Conducted analyzes of theses and master's theses led us to the conclusion that qualitative research and interpretations occur only in less than $20 \%$ of the cases studied. At the pedagogical faculty, surveying is used as the only research technique, and the analysis of the data obtained in this way is typically quantitative, and therefore very narrow, with low usefulness for practice. In the vast majority of cases studied, tables and graphs are included in the course of data analysis, while the interpretation descriptions are limited. It is also worrying that the presentation of research material carried out in this way very rarely ends with conclusions of evaluation or planning nature. Also the frequent withdrawal from the application of experimental research methodologies is disturbing, as they are crucial in the search for effective paths leading to the improvement of the quality and effectiveness of education. Similarly disturbing conclusions may be drwn from the analysis of many studies found in scientific pedagogical publications, in which the research is often limited to statistical diagnosis, often deprived of interpretation or inference. One may therefore wonder what are the goals in the research caracterised by such narrowed diagnostic and carried out without undertaking innovative and verification activities in the educational reality.

The issue of equality in education cannot be limited to talks. The actual quality in education means above all the quality of pedagogical activity and the tangible results obtained by all participants of educational processes. However, it can be seen in the literature that the cases of student failing to obtain minimum competences, reaching even a dozen or so percent of the sample, are often neglected. Meanwhile, every individual in the school class, as an educational subject, expects to experience changes under the influence of interactions caused in the course of the lesson process. Similarly, our research leads to the 
conclusion that in the education of students as future teachers, insufficient attention is paid to the independence of all students in the area of required teacher competences, which are supposed to be shaped.

At this point, special attention should be paid to the need to take into consideration the triangulation (selection) of research methods and techniques in teacher education. The dominant number of research works (master thesis and even published papers) that we have studied is characterized by a subjective one-sidedness in the analysis of the pedagogy phenomenon being studied. And this is very worrying as far as the importance of pedagogy as a social and practical science is concerned.

\section{CONCLUSIONS}

Analysis of quality in education - understood as a kind of evaluation in dialogue $\mathrm{e}^{20}$ - requires from teachers full competence in the areas of self-control, auto-correction and self-assessment, as well as control and evaluation of the effectiveness of pedagogical interactions. Conducted considerations allow for the formulation of a directive requirement, so that each graduate of teacher studies has the competence which allow:

- evaluating of various structural elements constituting the educational system,

- conducting qualitative research, and then developing and interpreting the obtained source data,

- respecting assumptions of "live" teaching in the course of subject teaching on everyday basis,

- diagnosing, evaluating pedagogical phenomena and designing new solutions ${ }^{21}$.

A lot of the content in teacher education should therefore deal with deliberately organized task situations, requiring evaluation on the basis of assimilated psychological, pedagogical, sociological and other theories. This should be the basis to make a good teacher competent for the practical action consistent with the premises of an adequately selected and justified theory ${ }^{22}$.

${ }^{20}$ J. Grzesiak, Lekcje i diagnostyka psychopedagogiczna dziecka. Konin, 2014;

J. Grzesiak, Przez analizę wartości ..., op. cit. s. 288.

${ }^{21}$ J. Grzesiak, Projektowanie dydaktyczne jako element kompetencji nauczyciela. In: W. Kojs, E. Piotrowski, T. Zimny (eds.), Edukacja jutra. Częstochowa, 2002, s. 528-534.

${ }_{22}^{2}$ J. Grzesiak, Problemy integracji kultury i edukacji szkolnej. In: J. Grzesiak (eds.), Edukacja i kultura. Kalisz, 2002, s. 174. 
To improve the work of higher schools and better prepare future teachers to perform their professional duties, it is necessary to conduct systematic research and qualitative analysis. In this regard, there is not only the need, but even the necessity to use educational dialogue on several levels, including:

- between academic teachers and academics,

- between academic teachers and methodological advisers,

- between teachers and students (and their "teachers"),

- between academic teachers and school directors in the aspect of pedagogical supervision,

- between teacher training centers and

- between universities educating teachers and teacher training centers as well as self-government and educational authorities.

The teacher's competences are used to multiply the effects of education and upbringing, however the teacher is by no means limited to act only on the theoretical basis. For this reason, the skills of teachers in the field of evaluation and self-assessment gain a lot of significance, due to their knowledge-creating and implementation dimension ${ }^{23}$. Evaluation in education, as a kind of value analysis, requires teachers to perform succesful self-control, self-correction and requires also the control and evaluation of the effectiveness of pedagogical interactions. On this basis, self-assessment is also possible and necessary, which in turn is closely related to the teacher's reflexivity and self-esteem. Reflection, on the other hand, is a manifestation of thinking, which is characterized by permanent inquiry, consideration and analysis of a given issue in a multi-aspect approach. The reflection often results from the feeling of uncertainty or non-compliance with specific standards as evaluation criteria. Thinking and reflective action manifest above all such qualities as: openness, responsibility, honesty and reliability ${ }^{24}$. Reflection in teacher's work is a kind of self-assessment of his/her pedagogical activity. This means that self-assessment is an intellectual process that

${ }^{23}$ J. Grzesiak, Samoocena ucznia a samoocena nauczyciela. In: J. Grzesiak (eds..), Ewaluacja $i$ innowacje $w$ edukacji, vol. 7, Kalisz- Konin, 2009, pp. 402-403; H. Kwiatkowska, Pedeutologia, Warszawa, 2008, s. 102-110.

${ }^{24} \mathrm{~J}$. Grzesiak, Interdyscyplinarne aspekty ksztaltowania kompetencji badawczych (przyszłych) nauczycieli. In: J. Grzesiak, I. Zymomrya, W. Ilnytskyj (eds.), Paradygmatyczne aspekty $i$ dylematy rozwoju nauk $i$ edukacji. Konin, - Użhorod Melitopol - Chersoń - Krzywy Róg, 2019, s. 54-65. 
causes specific changes in the sphere of teacher's professional knowledge and experience.

The didactic and educational process at school and at the university is a dynamic and "living" process. The situations it includes require from teachers and pupils ongoing evaluation and independent decision making. Therefore, in any well-organized education process one must not lack the reflexivity for satisfactory evaluation and self-assessment both on the part of the student and the teacher. The hierarchy of tasks and the gradability of reflexivity in the course of educational situations should be emphasized here, namely:

- reflective academic teacher,

- reflective teacher,

- reflective pupil $^{25}$.

We therefore come to emphasize particularly important relationships that exist between theory and practice, and indirectly between evaluation, reflexivity and assessment as well as selfassessment in education. All of these relationships have the mostimportant place in the course of apprenticeships for students preparing to work as teachers.

In the teaching-learning process, the teacher gradually limits the scope of his/her role as person responsbile for the transfer of knowledge, and is increasingly becoming a diagnostician, therapist, organizer and consultant. The significative title exposing the one-minute manager results also from the fact that, apart from the mastery in his/her work, he/she is a person willingly introducing others to the secrets of his/her success in wisdom. A one-minute manager can therefore be considered a model contemporary mentor ${ }^{26}$.

Knowing the individual style allows to better understand one's strengths and weaknesses, and the benefits of knowing the styles of team members' work help to better understand oneself and others and be better understood by them ${ }^{27}$. Let us mention here for example:

- improving the quality of education of students in the teaching faculties according to the standards defined by the university system and the Bologna process,

${ }^{25}$ J. Grzesiak, Samoocena ucznia...op.cit. s. 402-403.

${ }^{26} \mathrm{~K}$. Blanchard, Przywództwo wyższego stopnia. Warszawa, 2009.

${ }^{27}$ G.B. Moskovitz, Zrozumieć siebie i innych, Gdańsk 2009; see also: Karpińska A., Zapobieganie niepowodzeniom szkolnym. In: J. Grzesiak (eds.), Ewaluacja i innowacje w edukacji. Autoewaluacja i refleksyjność nauczyciela, Konin, 2007, s. 17-24. 
- acquiring by students practical skills necessary in the teaching profession in close connection with theoretical knowledge mainly: diagnosing students and student teams, selection of content and methods in relation to previously formulated operational goals, implementation of education and upbringing processes based on prepared scenario on diagnosis, evaluation of own achievements and pupils'achievements (in classes or student groups), planning teaching materials that complement textbook materials - to implement live teaching ${ }^{28}$.

The education of tomorrow relies on teachers ${ }^{29}$, states rightly professor Kazimierz Denek. Each academic teacher and every teacher is supposed to be the implementer of ambitious and responsible tasks of "education of the future" - but it requires full and consistent integration of pedagogical theory and practice.

\section{SUMMARY}

In the article issues of the human capital are being discussed in the education in the face of transformations in the contemporary and future society (of knowledge). The particular relevance is being assigned to categories of the quality of the education, qualities of educational examinations and the dialogue with respect to the improvement of the quality in the education. On that account the accent was put to categories of the human capital - especially in relating the education of teachers to the quality for today and on tomorrow. For fulfilling the common movement of pedagogic progress in the education a close relationship was emphasized between quality inspections and educations in the article formulated also became the quality methodological directives concerning educational examinations, including examinations of future teachers led in the course of studies parallel to processes of the theoretical and instrumental education. Theoretical considerations are illustrated with empirical examples. This refers in particular to the significant relationships emphasised in the text, which occur between theory and practice, as well as between reflectiveness and evaluation or self-evaluation in the process of language education. All of these relationships perform responsible functions in the course of internships

${ }^{28}$ J. Grzesiak, Nauczanie „żywe” i karty pracy we współczesnej szkole, in: K. Denek, T. Koszczyc, P. Oleśniewicz (red.), Edukacja Jutra, vol. 2. Wrocław, 2006, s. 209-217.

${ }^{29}$ K. Denek, Edukacja pozalekcyjna i pozaszkolna, Poznań, 2011; K. Denek: $O$ powodzeniu reformy edukacji zadecyduja kwalifikacje nauczycieli, „Ruch Pedagogiczny" 1998, no 3-4; K. Denek, Aksjologiczne aspekty edukacji szkolnej, Toruń, 1999. 
done by students preparing to work as teachers - in every case of a language teacher and the native country teacher. At the end, the author puts forward desiderata towards education - also in relation to language education and the studies of it.

\section{REFERENCES}

1. Blanchard K. Przywództwo wyższego stopnia. Warszawa, 2009. 1999.

2. Denek K. Aksjologiczne aspekty edukacji szkolnej. Toruń,

3. Denek K. Edukacja pozalekcyjna i pozaszkolna. Poznań, 2011.

4. Denek K. O nowy kształt edukacji. Toruń, 1998.

5. Denek K. O powodzeniu reformy edukacji zadecydują kwalifikacje nauczycieli. „, Ruch Pedagogiczny”. 1998. Nr 3-4. 1994.

6. Denek K. Wartości i cele edukacji szkolnej. Poznań-Toruń,

7. Denek K., Kuźniak I. Projektowanie celów kształcenia w reformowanej szkole. Poznań, 2001.

8. Grzesiak J. Rzut oka wstecz wobec edukacji jutra. In: K. Denek. T. Koszczyc, W. Starościak (eds.), Edukacja Jutra, tom 2. Wrocław, 2009.

9. Grzesiak J. Autoewaluacja i refleksyjność nauczyciela w pedeutologii. In: J. Grzesiak (eds.), Ewaluacja i innowacje w edukacji. Konin, 2007.

10. Grzesiak J. Ewaluacja w dialogu-dialog w ewaluacji. In: J. Grzesiak (eds.), Ewaluacja $i$ innowacje $w$ edukacji. Kalisz-Konin, 2008.

11. Grzesiak J. Interdyscyplinarne aspekty kształtowania kompetencji badawczych (przyszłych) nauczycieli. In: J. Grzesiak, I. Zymomrya, V. Ilnytskyj (eds.), Paradygmatyczne aspekty i dylematy rozwoju nauk $i$ edukacji. Konin - Użhorod - Melitopol - Chersoń Krzywy Róg, 2019.

12. Grzesiak J. Lekcje i diagnostyka psychopedagogiczna dziecka. Konin, 2014.

13. Grzesiak J. Metodologiczne uwarunkowania modelowania podręcznika dla klas początkowych. In: A. Mościcki (eds.), Teoretyczne $i$ praktyczne aspekty metodologii badań podręczników szkolnych. Koszalin, 1986.

14. Grzesiak J. Modelowanie projektowania poprawy jakości kształcenia wyzwaniem dzisiaj -wczoraj i jutro. In: J. Grzesiak (eds.), Ewaluacja i innowacje w edukacji. Kalisz - Konin, 2013. 
15. Grzesiak J. Nauczanie ,żywe” i karty pracy we współczesnej szkole. In: K. Denek, T. Koszczyc, P. Oleśniewicz (eds.), Edukacja Jutra, tom 2. Wrocław, 2006.

16. Grzesiak J. Podstawy teorii i metodyki kształcenia praktycznego nauczycieli. Kapitał Ludzki. Konin, 2010.

17. Grzesiak J. Podstawy teorii i metodyki kształcenia praktycznego nauczycieli. Konin, 2010.

18. Grzesiak J. Problemy integracji kultury i edukacji szkolnej. In: J. Grzesiak (eds.), Edukacja i kultura. Kalisz, 2002.

19. Grzesiak J. Projektowanie dydaktyczne jako element kompetencji nauczyciela. In: W. Kojs, E. Piotrowski, T. Zimny (eds.), Edukacja jutra. Częstochowa, 2002.

20. Grzesiak J. Przez analizę wartości do postępu pedagogicznego. In: T. Zacharuk (eds.), Ciagłość i zmiana w pedagogice XXI wieku, pt. 1. Siedlce, 2007.

21. Grzesiak J. Samoocena ucznia a samoocena nauczyciela. In: J. Grzesiak (eds.), Ewaluacja $i$ innowacje $w$ edukacji, t. 7. KaliszKonin, 2009.

22. Grzesiak J. Założone a rzeczywiste kompetencje nauczycieli wobec poprawy jakości kształcenia. In: A. Klim-Klimaszewska (eds.), Kompetencje współczesnego nauczyciela, tom 1. Siedlce, 2012.

23. Jankowski D. Autoedukacja wyzwaniem współczesności. Toruń, 1999.

24. Karpińska A. Zapobieganie niepowodzeniom szkolnym. In: J. Grzesiak (eds.), Ewaluacja i innowacje w edukacji. Autoewaluacja $i$ refleksyjność nauczyciela. Konin, 2007.

25. Kojs W. Funkcje teorii w działaniach edukacyjnych nauczyciela i ucznia - szkic analizy zagadnienia. In: J.Grzesiak (eds.), Ewaluacja $i$ innowacje w edukacji nauczycieli, tom 1. Kalisz, 2007.

26. Koziełecki J. Rozwiązywanie problemów. Warszawa, 1969.

27. Kwiatkowska H. Edukacja nauczycieli. Warszawa, 1997.

28. Kwiatkowska H. Pedeutologia. Warszawa, 2008.

29. Mastalski J. Etos nauczyciela XXI wieka a stereotypy edukacyjne. In: J. Grzesiak (eds.), Ewaluacja i innowacje w edukacji nauczycieli, tom 1. Kalisz, 2007.

30. Moskovitz G.B. Zrozumieć siebie i innych. Gdańsk, 2009.

31. Muszyński H. Pojęcie systemu i jego konsekwencje. In: W. Okoń (eds.), System dydaktyczny. Warszawa, 1972.

32. Niemierko B. Diagnostyka edukacyjna. Warszawa, 2012. 
33. Okoń W. O postępie pedagogicznym. Warszawa, 1970.

34. Okoń W. Podstawy wykształcenia ogólnego. Warszawa, 1968.

35. Palka S. Teoria pedagogiczna a praktyczne doświadczenia nauczycieli. Warszawa, 1989.

36. Palka S. Wiązanie operacji poznawczych i metodologicznych w pedagogicznych badaniach edukacyjnych. In: K. Denek, A. Kamińska, P. Oleśniewicz (eds.), Edukacja jutra. Tradycja i nowoczesność we wspótczesnej organizacji systemu kształcenia. Sosnowiec, 2013.

37. Rozporządzenie Ministra Edukacji Narodowej z dnia 17 stycznia 2012 r. w sprawie standardów ksztatcenia nauczycieli.

38. Suchodolski B. Dzieje kultury polskiej. Warszawa, 1986.

\section{Information about the author:}

Grzesiak Jan

Dr hab. in the field of Pedagogical Sciences, Professor at the State School of Higher Professional Education in Konin Department of Pedagogy and Social Work 4, Popiełuszki str., Konin, 62-510, Poland 